Original Research Paper

\title{
Characteristics of Host Trees as Habitat for Ephiphytic Orchids in the Cibereum waterfall Path, Mount Gede Pangrango, West Java
}

\author{
Bela Prapitasari ${ }^{1 *}$ \& Ardyan Pramudya Kurniawan ${ }^{1}$ \\ ${ }^{1}$ Laboratorium Ekologi Botani Universitas Islam Negeri (UIN) Sunan Kalijaga, Jalan Marsda \\ Adisucipto 55281, Yogyakarta, Indonesia.
}

\author{
Article History \\ Received : August $04^{\text {th }}, 2021$ \\ Revised : August $27^{\text {th }}, 2021$ \\ Accepted : September 05 ${ }^{\text {th }}, 2021$ \\ Published : September 15 $5^{\text {th }}, 2021$ \\ *Corresponding Author: \\ Bela Prapitasari, \\ Laboratorium Ekologi Botani \\ Universitas Islam Negeri (UIN) \\ Sunan Kalijaga, Jalan Marsda \\ Adisucipto 55281, Yogyakarta, \\ Indonesia. Email: \\ belaprapitasari@gmail.com
}

\begin{abstract}
An epiphytic orchid is one type of orchid that has the characteristics of habitat attached to the host tree. Mount Gede Pangrango, especially in the Cibereum waterfall, Selabintana, is a tropical forest area with many large host trees with a lush canopy, causing the epiphytic orchid species to form be abundant in the area. This study aims to determine the type and characteristics of the host tree used as a habitat for epiphytic orchids in the Cibereum waterfall path. The research method is to make ten plots on the right and left sides of the path, with each plot measuring 500x5 m and the distance between plots is $100 \mathrm{~m}$. The results showed that on the Cibereum waterfall path, 33 species of host trees were found, consisting of 20 families. At the same time, the types of orchids found were 31 species from 12 genera. Almost all of the orchid hosts are trees, except for Brassaiopsis glomerulata are shrubs and Cyathea sp are poles. The characteristics of host trees as habitat for epiphytic orchids are: 4-51 m tall, trunk diameter 7-89 $\mathrm{cm}$, canopy width $0-20 \mathrm{~m}$, bark thickness $0-1.2 \mathrm{~cm}$, bark texture rough to medium, generally colored brown, has no sap except for Ficus variegata, the surface of the trunk contains moss, and the epiphytic orchid growth zone on the host tree is mostly found in zones III and IV.
\end{abstract}

Keywords: Epiphytic Orchid, Cibereum waterfall, Host Tree, Characteristics, Habitat

\section{Pendahuluan}

Beberapa jenis tumbuhan epifit sebagian besar tumbuh pada berbagai jenis pohon besar di hutan-hutan tropis. Tumbuhan epifit tersebut menempel pada celah-celah retakan kulit pohon dengan percabangan yang besar. Semakin tua umur pohon maka kulit pohon akan semakin kasar, banyak celah, dan memiliki banyak percabangan besar. Akan tetapi tidak semua jenis pohon yang umurnya sudah tua meskipun memiliki jenis yang sama akan ditumbuhi tumbuhan epifit yang melimpah. Hal tersebut karena kemelimpahan tumbuhan epifit dipengaruhi oleh kondisi substrat atau kulit pohon yang terdiri dari kemiringan dan kekerasan kulit (Sujalu, 2015). Salah satu jenis tumbuhan epifit adalah anggrek yang habitatnya menempel pada pohon inang baik yang sudah mati atau hidup (Hasanuddin, 2010).

Pohon inang menjadi salah satu kebutuhan utama anggrek epifit, dimana kebutuhan cahaya dan sirkulasi udara akan terpenuhi secara optimal (Madison 1977 dalam Puspitaningtyas, 2007). Sadili (2013) juga menyatakan bahwa habitat anggrek epifit umumnya ditemukan pada pohon inang yang memiliki tekstur tidak rata, kasar, dan retakretak. Kondisi tersebut menyebabkan kotoran, air, dan humus akan mudah menempel pada kulit batang. Semakin lama menumpuknya kotoran, air, dan humus maka akan menyebabkan batang pohon tersebut menjadi lembab dan cocok untuk pertumbuhan anggrek epifit. Selain karakteristik kulit pohon, pohon 
yang berukuran besar dan bertajuk tinggi juga akan menyebabkan persebaran anggrek epifit lebih mudah menyebar pada kawasan hutan yang luas.

Kondisi kawasan hutan juga mempengaruhi keragaman anggrek epifit. Seperti di kawasan Gunung Gede Pangrango Jawa Barat, khususnya di Resort Selabintana kawasan hutan masih terjaga dengan baik. Terbukti masih banyak dijumpai pohon inang berukuran besar dan memiliki kanopi yang rimbun menyebabkan jenis anggrek melimpah di kawasan tersebut. Menurut Prapitasari et al., (2020) terdapat 46 jenis anggrek (25 epifit dan 21 terestrial) di Resort Selabintana pada jalur curug Cibereum dan jalur pendakian hingga ketinggian $1.500 \mathrm{mdpl}$. Akan tetapi jenis pohon inang yang terdeskripsikan hanya sedikit yakni Cyathea sp, Schima walichii, Ficus sp, dan pohon mati (Prapitasari et al., 2020). Berdasarkan pemaparan tersebut penelitian ini bertujuan untuk mengetahui jenis serta karakteristik pohon inang sebagai habitat anggrek epifit di sepanjang jalur menuju Curug Cibereum mengingat penelitian sebelumnya hanya sedikit pohon inang yang terdeskripsikan.

\section{Bahan dan Metode}

\section{Waktu dan Tempat}

Penelitian dilakukan pada bulan Maret 2021 di Resort Selabintana Gunung Gede Pangrango pada jalur menuju Curug Cibereum dengan ketinggian 1100-1400 mdpl.

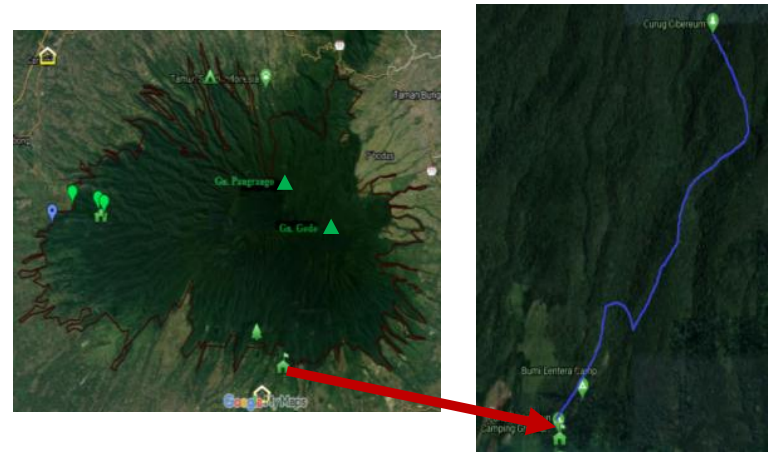

Gambar 1. Lokasi penelitian, garis biru merupakan jalur Curug Cibereum

\section{Alat dan Bahan}

Alat yang digunakan dalam penelitian ini yaitu tallysheet, kamera, metline, penggaris, hagameter, dan GPS.

\section{Teknik Pengumpulan Data}

Pengambilan data dilakukan dengan metode plot yang diletakkan di sisi kanan dan kiri jalur curug sebanyak 10 buah dengan masingmasing plot berukuran panjang $500 \mathrm{~m}$ dan lebar 5 $\mathrm{m}$ serta jarak antar plot $100 \mathrm{~m}$. Data yang diambil berupa jenis pohon inang (nama latin dan nama lokal), tektur kulit batang, tinggi pohon, lebar kanopi, diameter batang, ada tidaknya getah, ketebalan kulit, zonasi pertumbuhan anggrek epifit, dan jenis anggrek epifit yang menempel pada pohon inang.

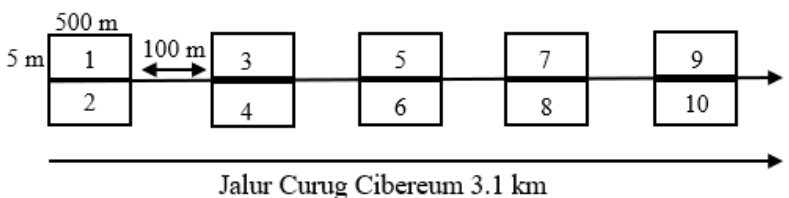

Gambar 2. Desain sampling teknik pengambilan data

Kemudian untuk jenis anggrek epifit yang ditemukan pada pohon inang, diamati distribusinya berdasarkan kaidah Johanson 1975 (Effendi et al., 2019).
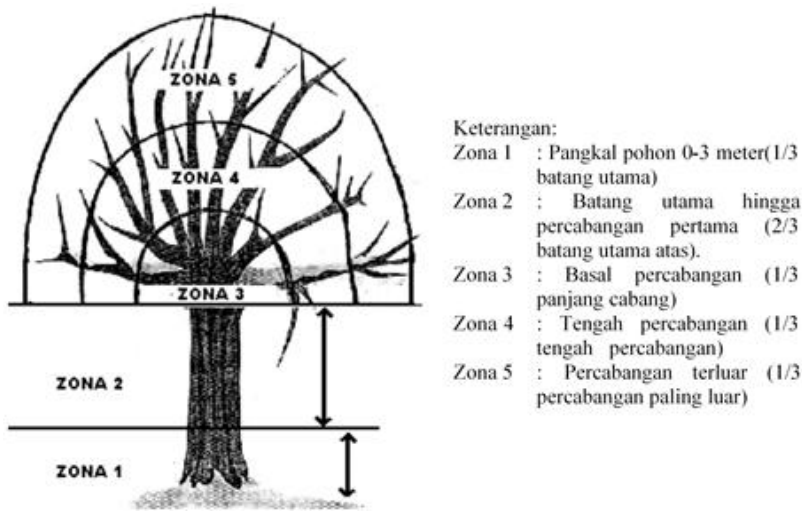
percabangan paling luar)

Gambar 3. Pembagian zonasi pertumbuhan anggrek epifit berdasarkan kaidah Johanson 1975 (Marsusi et al., 2001)

\section{Analisis Data}

Analisis data dilakukan secara deskriptif yaitu dengan mendeskripsikan karakter morfologi pohon inang berdasarkan hasil pengamatan dan pengukuran. Nama lokal serta identifikasi pohon inang anggrek epifit berdasarkan buku "Panduan Lapangan Jenis-Jenis Tumbuhan Restorasi" (Desitarani et al., 2014), "A picture Guide of Forest Plants in Gunung Gede Pangrango National Park, Indonesia" (Tagane et al., 2018), serta jurnal "Kekayaan Jenis Pohon di Hutan Taman Nasional Gunung Gede Pangrango, Jawa Barat" (Rozak et al., 2016). 


\section{Hasil dan Pembahasan}

\section{Jenis Pohon Inang Anggrek Epifit}

Berdasarkan hasil penelitian, ditemukan sebanyak 33 jenis pohon inang ( 1 jenis berupa pohon mati) anggrek epifit yang terdiri dari 20 Famili dengan jumlah individu sebanyak 121.
Sebagian besar inang anggrek epifit di Jalur Curug Cibereum termasuk dalam kategori pohon dan terdapat satu jenis berupa perdu yaitu Brasiaopsis glomerulata dan satu jenis berupa kategori tiang yaitu Cyathea sp (Paku Tiang) yang termasuk dalam kategori tumbuhan tingkat bawah tetapi secara morfologinya menyerupai pohon (Tabel 1)

Tabel 1. Jenis-jenis pohon inang anggrek epifit di Jalur Curug Cibereum

\begin{tabular}{|c|c|c|c|c|c|}
\hline No & Famili & Pohon & Nama Lokal & Jumlah & Keterangan \\
\hline 1 & Actinidiaceae & Saurauia blumiana & Ki Leho & 1 & Pohon \\
\hline 2 & Altingiaceae & Altingia excelsa & Rasamala & 9 & Pohon \\
\hline 3 & Annonaceae & Orophea hexandra & Sauheun & 3 & Pohon \\
\hline \multirow{2}{*}{4} & \multirow{2}{*}{ Araliaceae } & Schefflera aromatica & Jangkorang & 7 & Pohon \\
\hline & & Brassaiopsis glomerulata & Juluk-julukantu & 1 & Perdu \\
\hline \multirow{2}{*}{5} & \multirow{2}{*}{ Cannabaceae } & Trema orientalis & Kuray & 1 & Pohon \\
\hline & & Cetlis timorensis & Ki Tamiang & 2 & Pohon \\
\hline 6 & Cornaceae & Alangium rotundifolium & Ki Careuh & 2 & Pohon \\
\hline 7 & Cyatheaceae & Cyathea sp & Paku Tiang & 1 & Tiang \\
\hline \multirow{4}{*}{8} & \multirow{4}{*}{ Elaeocarpaceae } & Sloanea sigun & Beleketebe & 6 & Pohon \\
\hline & & Elaeocarpus acronodia & Mendang & 2 & Pohon \\
\hline & & Elaeocarpus stipularis & Janitri Gede & 3 & Pohon \\
\hline & & Elaeocarpus sp & - & 3 & Pohon \\
\hline \multirow[t]{2}{*}{9} & Euphorbiaceae & Macaranga rhizinoides & Mahang Perak & 3 & Pohon \\
\hline & & Castanopsis javanica & Riung Anak & 8 & Pohon \\
\hline \multirow{3}{*}{10} & Fagaceae & Castanopsis tungurrut & Ki Tungeureut & 4 & Pohon \\
\hline & & Castanopsis argentena & Saninten & 1 & Pohon \\
\hline & & Lithocarpus sundaicus & Pasang & 1 & Pohon \\
\hline 11 & Juglandaceae & Engelhardia spicata & Ki Hujan & 3 & Pohon \\
\hline \multirow{2}{*}{12} & \multirow{2}{*}{ Moraceae } & Ficus variegata & Kondang & 9 & Pohon \\
\hline & & Ficus grewiifolia & - & 1 & Pohon \\
\hline \multirow{3}{*}{13} & \multirow{3}{*}{ Myrtaceae } & Syzigium laxiflorum & Tiangpang & 1 & Pohon \\
\hline & & Syzigium rostratum & Ki Sereum & 1 & Pohon \\
\hline & & Syzigium $s p$ & Salam & 3 & Pohon \\
\hline 14 & Pentaphyllaceae & Eurya acuminata & Ki Sapu & 3 & Pohon \\
\hline 15 & Phyllanthaceae & Bridelia insulana & Ki Pahang & 1 & Pohon \\
\hline 16 & Rosaceae & Prunus arborea & Ceri Kawoyang & 1 & Pohon \\
\hline \multirow{2}{*}{17} & \multirow{2}{*}{ Rubiaceae } & Dicospermum abnore & Kokopian & 2 & Pohon \\
\hline & & Neonauclea obtusa & Cangcaratan & 8 & Pohon \\
\hline 18 & Staphyleaceae & Turpinia pomifera & Ki Bantet & 2 & Pohon \\
\hline 19 & Theaceae & Schima wallichii & Puspa & 21 & Pohon \\
\hline \multirow[t]{2}{*}{20} & Urticaceae & Oreocnide rubescens & Ngangsi & 7 & Pohon \\
\hline & & JUMLAH & & 121 & \\
\hline
\end{tabular}


Semua jenis pohon inang yang ditemukan memiliki kriteria yang cocok untuk pertumbuhan anggrek epifit yaitu memiliki kulit pohon yang kasar, lembab, dan terdapat lumut. Famili pohon inang yang paling banyak ditemukan yaitu Elaeocarpaceae (Elaeocarpus sp, E. acronodia, E. stipularis, S. sigun), Fagaceae (C. javanica, $C$. argentena, $C$. tungurrut, $L$. sundaicus), dan Myrtaceae (Syzigium sp, $S$. laxiflorum, $S$. rostratum). Ketiga famili pohon tersebut terdiri dari pohon berukuran besar yang cocok untuk pertumbuhan anggrek epifit karena lebih rindang dan sejuk (Sumarni et al., 2019).

Pohon inang yang paling banyak ditemukan yaitu $S$. walichii (puspa) sebanyak 21 individu. Hal tersebut karena pada kawasan sub montana (1.100$1.500 \mathrm{mdpl}$ ) Gunung Gede Pangrango didominasi oleh pohon-pohon besar dan tinggi seperti $S$. walichii. Kanopi yang luas menyebabkan terjadinya peningkatan kelembaban karena berkurangnya intensitas cahaya matahari, sehingga lingkungan di bawah kanopi memiliki temperatur rendah dan relatif basah yang menyebabkan anggrek epifit tumbuh optimal (Setyawan, 2000). Selain S. walichii, pohon inang yang dijumpai cukup banyak yaitu $A$. excelsa dan $F$. variegata masing-masing sebanyak 9 individu, N. obtusa sebanyak 8 individu, $S$. aromatica dan $O$. rubescens masing-masing sebanyak 7 individu.

A. excelsa (rasamala) merupakan pohon berukuran besar dengan diameter batang mencapai $200 \mathrm{~cm}$ dan ketinggiannya mencapai $60 \mathrm{~m}$. Sama seperti $S$. walichii, $F$. variegata juga merupakan pohon berukuran besar dengan diameter mencapai $70 \mathrm{~cm}$ dengan tinggi mencapai $30 \mathrm{~m}$ (Desitarani et al., 2014). F. variegata merupakan pohon inang yang paling banyak dijumpai jenis anggrek epifit dalam satu pohon. Kedua jenis pohon tersebut cocok untuk pertumbuhan anggrek epifit karena memiliki perawakan yang besar, tinggi, kondisi kulit kasar, dan memiliki naungan lebar. Berbeda dengan penelitian lainnya yang menyebutkan bahwa pada tegakan hutan rasamala tidak dijumpai anggrek epifit sama sekali karena kulit pohonnya cenderung halus dan percabangan pertama terletak sangat dekat dengan kanopi (Paramitha et al., 2010). Sadili \& Siti (2017), juga menyatakan bahwa pada hutan homogen rasamala masih dijumpai jenis anggrek epifit walaupun jumlahnya sedikit dan tidak bervariasi. Perbedaan hasil penelitian tersebut terjadi karena usia pohon yang berbeda dimana pada jalur Curug Cibereum rasamala ditemukan sudah tua (berukuran besar) dan terdapat pada hutan heterogen dengan keanekaragaman hayati tinggi. $N$. obtusa dan S. aromatica sebagai inang anggrek epifit tidak jauh berbeda dengan pohon-pohon sebelumnya karena berperawakan besar, tinggi, bercabang banyak, permukaan kulitnya kasar, dan mengandung banyak air serta unsur hara yang dibutuhkan anggrek epifit (Marsusi et al., 2015). O. rubescens walaupun pohon dengan perawakan kecil dengan diameter $20 \mathrm{~cm}$ dan tingginya $8 \mathrm{~m}$ (Desitarani et al., 2014), pohon tersebut dijumpai cukup banyak sebagai inang anggrek epifit karena permukaan yang kasar, lembab, dan banyak ditumbuhi lumut.

Pohon $O$. hexandra, $C$. timorensis, $A$. rotundifolium, $M$. rhizinoides, D. abnore, dan $T$. pomifera yang ditemukan 2-3 individu. Pohon tersebut juga digunakan sebagai inang anggrek epifit karena memiliki kriteria yang cocok untuk pertumbuhan anggrek epifit. Sedangkan pohon inang yang paling sedikit ditemukan dengan masing-masing berjumlah 1 individu yaitu $S$. blumiana, B. glomerulata, Cyathea sp, T. orientalis, $B$. insulana, dan $P$. arborea. Pohon inang yang ditemukan sedikit, menandakan bahwa tidak semua jenis anggrek cocok untuk tumbuh pada pohon tersebut. S. blumiana merupakan pohon dengan perawakan kecil, percabangannya banyak, permukaan kulitnya kasar, tetapi pohon tersebut memiliki buah yang sangat banyak pada batang utamanya sehingga anggrek epifit hanya akan menempel pada bagian setelah batang utama. Selanjutnya $B$. glomerulata merupakan perdu dengan batang kecil dan bagian percabangan pertama menuju cabang memiliki duri sehingga tidak semua jenis anggrek cocok untuk tumbuh pada pohon tersebut (Wawangningrum \& Dwi, 2008). Cyathea sp (paku tiang) merupakan tumbuhan tingkat bawah yang menyerupai pohon tetapi memiliki kulit yang berongga dan teksturnya kasar serta kelembabannya tinggi karena air mudah tertahan pada batang pohon tersebut sehingga sangat cocok untuk pertumbuhan anggrek epifit (Murtiningsih et al., 2016).

Keberadaan anggrek epifit pada pohon inang dipengaruhi oleh zonasi pertumbuhan. Hasil pengamatan menunjukkan ditemukan sebanyak 31 spesies anggrek epifit yang terdiri dari 12 genus. Anggrek epifit tersebut hidup pada berbagai jenis pohon inang yang tersebar pada berbagai zonasi pertumbuhan sesuai dengan habitat yang cocok (tabel 2 
Tabel 2. Jenis anggrek epifit beserta zonasi pertumbuhannya dalam pohon inang

\begin{tabular}{|c|c|c|c|c|c|c|c|}
\hline \multirow{2}{*}{ No } & \multirow{2}{*}{ Jenis Anggrek } & \multicolumn{5}{|c|}{ Zonasi Pohon Inang } & \multirow{2}{*}{$\begin{array}{l}\text { Jumlah Jenis } \\
\text { Pohon Inang }\end{array}$} \\
\hline & & $\mathbf{I}$ & II & III & IV & $\mathbf{V}$ & \\
\hline 1 & Agrostophyllum bicuspidatum & & $\begin{array}{l}\text { 1. E. acuminata } \\
\text { 2. O. hexandra }\end{array}$ & $\begin{array}{l}\text { 1. C. tungurrut } \\
\text { 2. S. walichii }\end{array}$ & 1. Syzigium $\mathrm{sp}$ & & 5 \\
\hline 2 & Agrostophyllum laxum & & 1. N. obtusa & $\begin{array}{l}\text { 1. C. tungurrut } \\
\text { 2. Elaeocarpus } \mathrm{sp} \\
\text { 3. E. spicata } \\
\text { 4. S. walichii }\end{array}$ & $\begin{array}{l}\text { 1. Elaeocarpus } \mathrm{sp} \\
\text { 2. L. sundaicus } \\
\text { 3. N. obtusa } \\
\text { 4. Syzigium } \mathrm{sp}\end{array}$ & & 8 \\
\hline 3 & Appendicula angustifolia & 1. B. insulana & $\begin{array}{l}\text { 1. N. obtusa } \\
\text { 2. O. rubescens } \\
\text { 3. S. aromatica } \\
\text { 4. S. sigun }\end{array}$ & $\begin{array}{l}\text { 1. N. obtusa } \\
\text { 2. O. rubescens } \\
\text { 3. S. aromatica } \\
\text { 4. S. sigun } \\
\text { 5. T. pomifera }\end{array}$ & $\begin{array}{l}\text { 1. F. variegata } \\
\text { 2. O. rubescens } \\
\text { 3. S. sigun } \\
\text { 4. Syzigium } \mathrm{sp}\end{array}$ & & 7 \\
\hline 4 & Appendicula cornuta & & & 1. Pohon Mati & & & 1 \\
\hline 5 & Adenoncos virens & & & 1. S. walichii & & & 1 \\
\hline 6 & Bulbophyllum capitatum & & $\begin{array}{l}\text { 1. M. rhizinoides } \\
\text { 2. O. hexandra } \\
\text { 3. T. pomifera }\end{array}$ & 1. S. walichii & 1. Elaeocarpus $\mathrm{sp}$ & & 5 \\
\hline 7 & Bulbophyllum multiflora & 1. S. walichii & $\begin{array}{l}\text { 1. A. excelsa } \\
\text { 2. C. argentena } \\
\text { 3. S. walichii }\end{array}$ & $\begin{array}{l}\text { 1. S. aromatica } \\
\text { 2. S. walichii } \\
\text { 3. Syzigium } \mathrm{sp}\end{array}$ & 1. Elaeocarpus $\mathrm{sp}$ & & 6 \\
\hline 8 & Bulbophyllum gibbosum & 1. A. rotundifolium & $\begin{array}{l}\text { 1. A. excelsa } \\
\text { 2. C. javanica } \\
\text { 3. F. variegata } \\
\text { 4. S. walichii }\end{array}$ & $\begin{array}{l}\text { 1. N. obtusa } \\
\text { 2. S. aromatica } \\
\text { 3. S. walichii } \\
\text { 4. Syzigium } \mathrm{sp}\end{array}$ & $\begin{array}{l}\text { 1. A. excelsa } \\
\text { 2. Elaeocarpus } \mathrm{sp} \\
\text { 3. L. sundaicus } \\
\text { 4. Syzigium } \mathrm{sp}\end{array}$ & 1. O. rubescens & 12 \\
\hline 9 & Bulbophyllum sp 1 & & & 1. S. laxiflorum & & & 1 \\
\hline 10 & Bulbophyllum sp 2 & 1. E. stipularis & & 1. S. laxiflorum & & & 2 \\
\hline 11 & Bulbophyllum sp 3 & & $\begin{array}{l}\text { 1. C. javanica } \\
\text { 2. C. tungurrut }\end{array}$ & $\begin{array}{l}\text { 1. C. javanica } \\
\text { 2. N. obtusa } \\
\text { 3. O. rubescens } \\
\text { 4. S. walichii } \\
\text { 5. Pohon Mati }\end{array}$ & $\begin{array}{l}\text { 1. C. tungurrut } \\
\text { 2. F. variegata }\end{array}$ & & 7 \\
\hline 12 & Ceratostylis anceps & & & $\begin{array}{l}\text { 1. E. stipularis } \\
\text { 2. E. acuminata }\end{array}$ & 1. E. spicata & & 3 \\
\hline
\end{tabular}


Prapitasari \& Kurniawan (2021). Jurnal Biologi Tropis, 21 (3): 706 - 719 DOI: http://dx.doi.org/10.29303/jbt.v21i3.2857

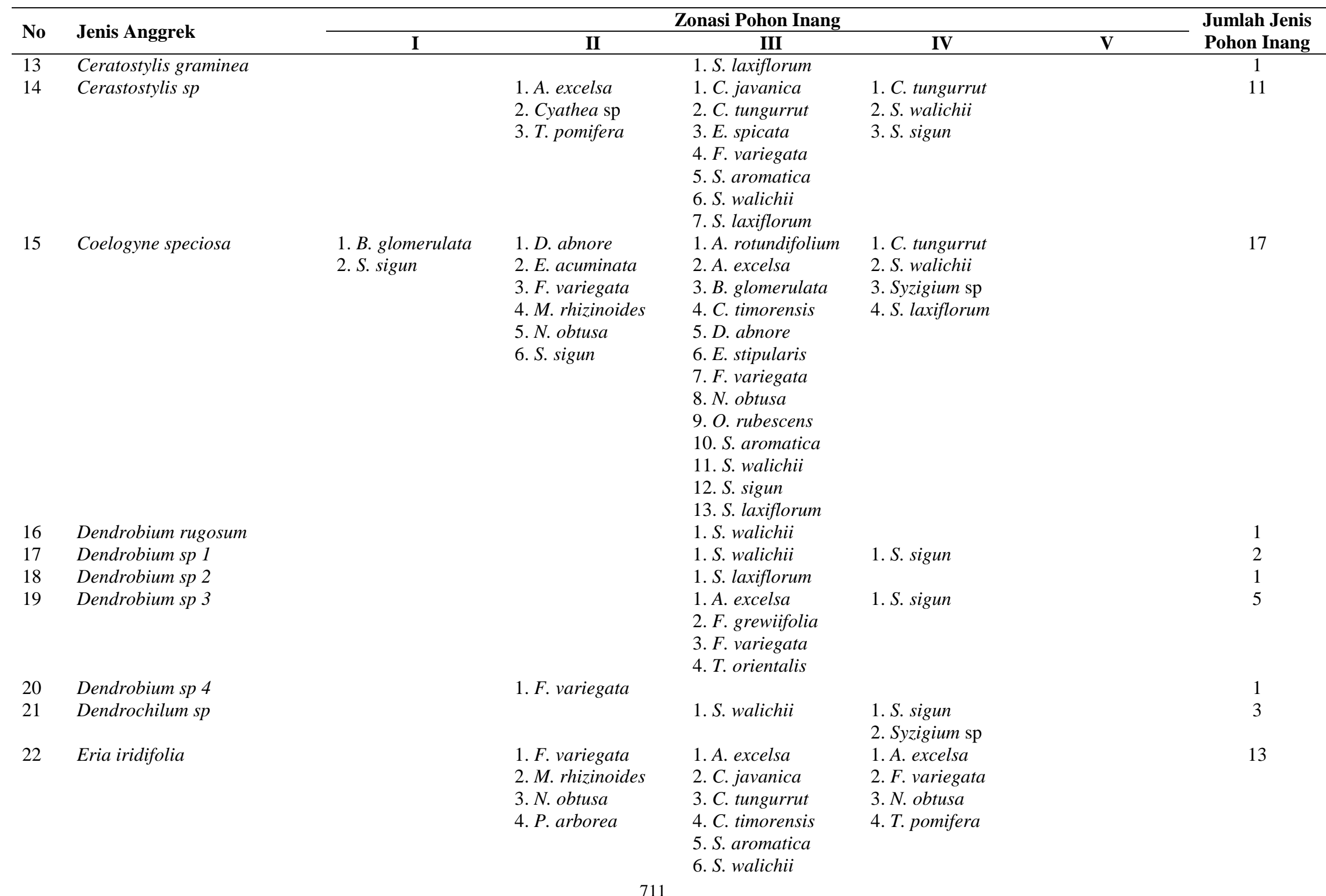




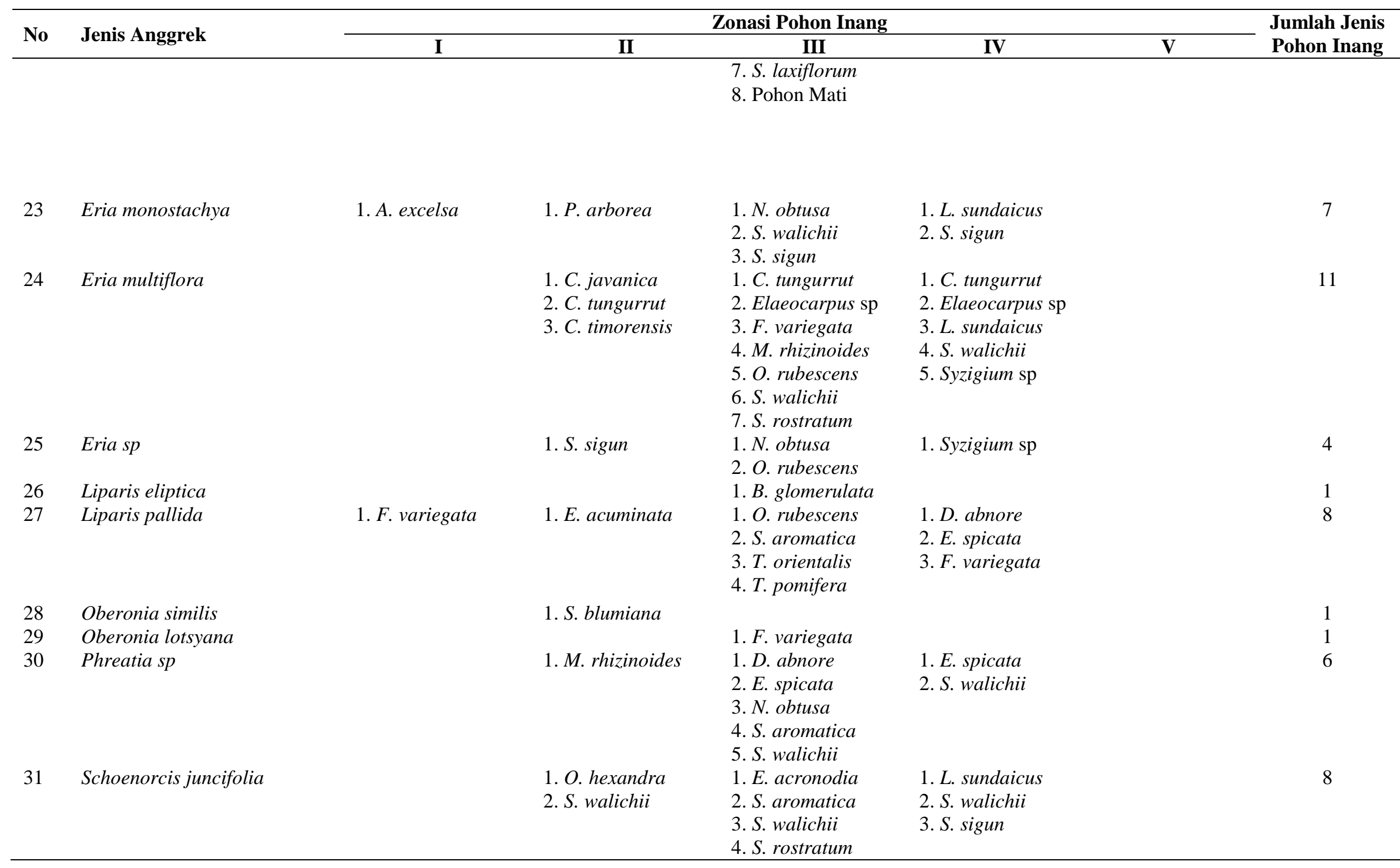




\section{Anggrek Epifit dan Zonasi pada Pohon Inang}

Berdasarkan tabel 2, anggrek epifit di Jalur Curug Cibereum sebagian besar ditemukan pada berbagai jenis pohon inang. Adapun anggrek epifit yang paling banyak ditemukan pada pohon inang adalah $C$. speciosa sebanyak 17 pohon inang, E. iridifolia sebanyak 13 pohon inang, Cerastostylis sp dan E. multilora ditemukan pada 11 pohon inang. Anggrek epifit lain seperti $S$. juncifolia, Liparis sp, C. anceps, A. laxum, A. bicuspidatum, A. angustifolia, juga ditemukan pada $>3$ pohon inang. Jenis-jenis anggrek epifit tersebut tidak memilih inang khusus untuk pertumbuhannya. Artinya jika kondisi pohon inang tersebut mampu menyediakan iklim mikro untuk pertumbuhan anggrek epifit, maka jenisjenis anggrek epifit tersebut akan mudah beradaptasi pada berbagai jenis pohon inang.

Genus anggrek paling banyak ditemukan seperti Bulbophyllum, Dendrobium, dan Eria juga tidak memilih inang khusus untuk pertumbuhannya karena anggrek tersebut ditemukan pada berbagai jenis pohon inang. Genus Bulbophyllum merupakan anggrek yang mudah beradaptasi pada berbagai jenis lingkungan. Genus Dendrobium yang terdiri dari $<1500$ jenis memungkinkan memiliki persebaran yang luas dari dataran rendah hingga tinggi serta memiliki adaptasi yang mudah pada berbagai kondisi lingkungan. Sedangkan genus Eria juga banyak ditemukan pada hutan hujan tropis (Siregar et al., 2005; Fandani et al., 2018).

Akan tetapi terdapat beberapa jenis anggrek epifit yang ditemukan pada pohon inang tertentu. Adapun anggrek tersebut yakni $A$. cornuta yang hanya ditemukan pada pohon mati, A. virens yang hanya ditemukan pada $S$. walichii, $C$. graminea yang hanya ditemukan pada $S$. laxiflorum, L. elliptica yang hanya ditemukan pada $S$. aromatica, $O$. similis yang hanya ditemukan pada inang $S$. blumiana, dan $O$. lotsyana yang hanya ditemukan pada $F$. variegata. Sebenarnya anggrek $O$. similis dan $O$. lotsyana tidak hanya ditemukan pada pohon $S$. blumiana dan $F$. variegata, tetapi juga ditemukan pada pohon lain seperti S. walichii, Syzigium, dan Agathis disekitar lokasi penelitian. Kebetulan di sepanjang Jalur Curug Cibereum hanya ditemukan pada $S$. blumiana dan $F$. variegata. Anggrek epifit yang hanya dijumpai pada inang tertentu jumlahnya hanya sedikit yakni terdiri dari beberapa individu saja. Alasan anggrek epifit memilih inang khusus disebabkan kehidupan anggrek epifit sangat bergantung pada kondisi iklim mikro tegakan hutan, sehingga akan mempengaruhi tingkat pertumbuhan dan bagian-bagian pohon yang menjadi habitat anggrek epifit. Oleh karena itu, beberapa anggrek epifit hanya ditemukan pada pohon tertentu dan bagian pohon tertentu (Febriliani et al., 2013).

Anggrek epifit yang ditemukan di Jalur Curug Cibereum pertumbuhannya tersebar pada berbagai zonasi di pohon inang (tabel 2). Zonasi pertumbuhan anggrek epifit terbagi menjadi zona I-V. Zonasi yang paling banyak ditemukan anggrek epifit adalah zona III, IV dan II. Zona III merupakan daerah yang meliputi basal percabangan atau $1 / 3$ bagian dari total panjang cabang. Banyaknya anggrek epifit yang ditemukan pada zona tersebut karena kemampuan zona III untuk menyimpan air dan zat hara yang paling besar. Hal tersebut disebabkan karena zona III terdiri dari cabang yang paling besar dan memiliki derajat kemiringan paling kecil dibandingkan dengan zona lainnya. Sehingga memungkinkan dekomposisi berbagai jenis serasah dan debu, serta mampu menahan air hujan atau embun yang dibutuhkan oleh anggrek epifit (Syarif \& Efri, 2018). Zona IV merupakan zona tengah percabangan, dimana pada zonasi tersebut juga banyak ditemukan jenis anggrek. Pada zona IV ditemukan 20 jenis anggrek epifit. Habitat yang cocok untuk pertumbuhan anggrek epifit adalah zona III dan zona IV (Effendi et al., 2019). Zona II merupakan daerah batang utama hingga batas percabangan. Zona tersebut terletak diatas zona I yang memiliki kemiringan $90^{\circ}$. Akan tetapi jenis anggrek yang ditemukan cukup banyak yakni 17 jenis.

Zona yang paling sedikit ditemukan anggrek epifit adalah zona I dan V. Zona I dan V merupakan zona yang jarang ditempeli oleh anggrek epifit. Adapun anggrek yang ditemukan pada zona I sebanyak 7 jenis yaitu $A$. angustifolia dengan inang $B$. insulana, $B$. multiflora dengan inang $S$. walichii, B. gibbosum dengan inang $A$. rotundifolium, Bulbophyllum sp 2 dengan inang $E$. stipularis, $C$. speciosa dengan inang $E$. glomerulata dan $S$. sigun, E. monostachya dengan inang A. excelsa, serta Liparis pallida dengan inang $F$. variegata. Zona I yang terletak pada pangkal batang pohon yang menyulitkan 
anggrek epifit untuk menempel pada pohon inang karena memiliki derajat kemiringan hampir $90^{\circ}$. Selain itu pada wilayah zona I sedikit mendapat paparan cahaya matahari karena terhalang oleh kanopi dan vegetasi lain di sekitarnya. Sedangkan zona V merupakan zona yang terletak di ujung pohon dengan ukuran cabang-cabang pohon yang kecil, sering tertiup angin, dan intensitas cahaya matahari sangat besar karena terpapar sinar matahari langsung
(Marsusi et al., 2001). Pada zona V hanya ditemukan anggrek $B$. gibbosum pada pohon inang $O$. rubescens. Anggrek tersebut merupakan anggrek yang tidak memiliki pseudubolb. Hal tersebut sesuai dengan penelitian Effendi et al., (2019) bahwa pada zona V hanya ditemukan jenis anggrek yang berukuran kecil dan memiliki pseudubolb kecil atau tidak memiliki pseudobulb sama sekali.
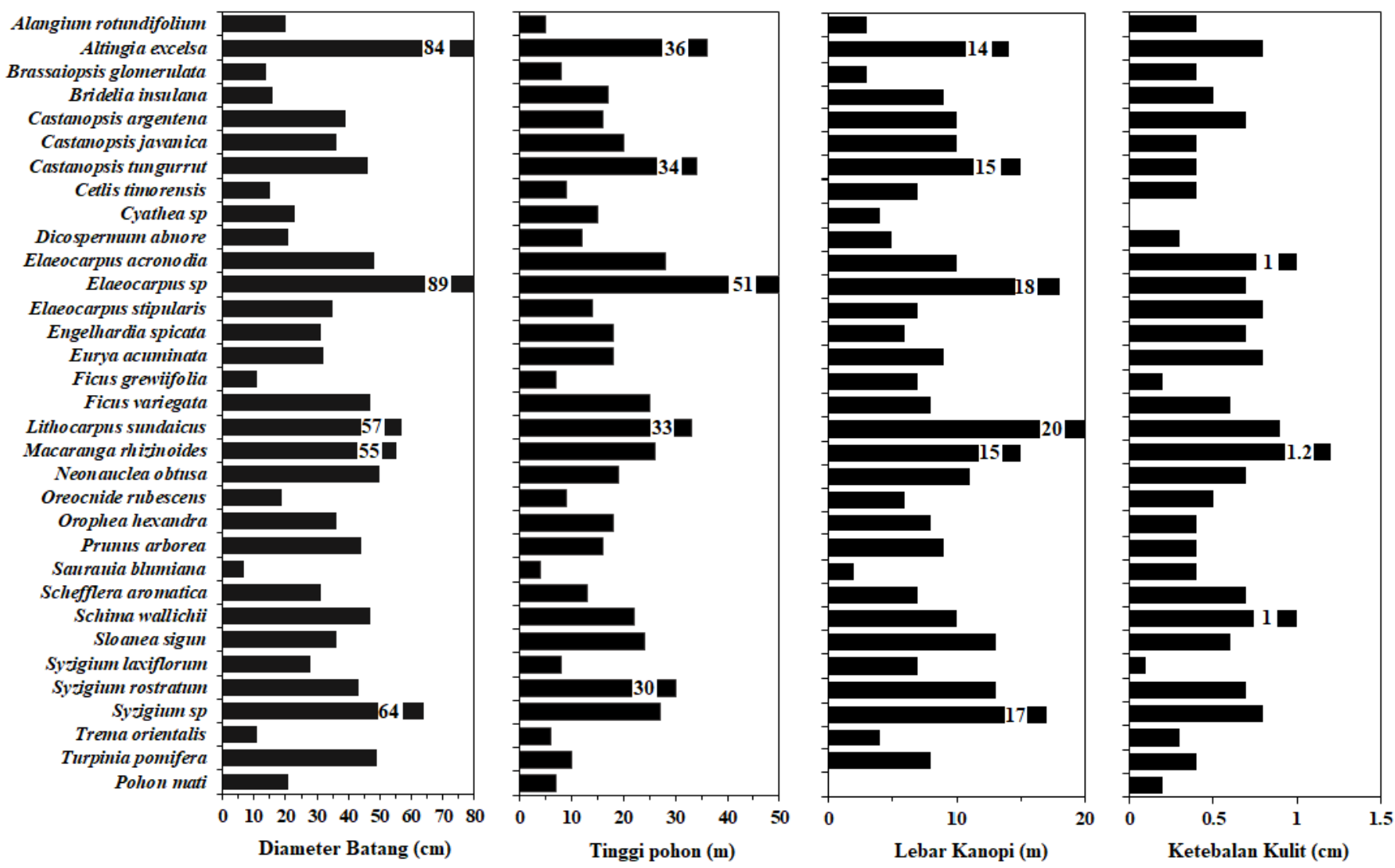

Gambar 3. Parameter fisik pohon inang anggrek epifit di Jalur Curug Cibereum

\section{Karakteristik Pohon Inang Anggrek Epifit}

Pohon inang yang ditempeli jenis-jenis anggrek epifit di atas, memiliki karakteristik sendiri sebagai habitat untuk pertumbuhan anggrek epifit. Hal tersebut karena tidak semua pohon dapat menjadi inang anggrek epifit. Adapun karakteristik dari pohon inang yang mempengaruhi kehadiran anggrek epifit dilihat berdasarkan perawakan pohon yang meliputi diameter batang, tinggi pohon, lebar kanopi, dan ketebalan kulit (Gambar 3). Diameter batang pohon terbesar yaitu pada Elaeocarpus sp yaitu $89 \mathrm{~cm}$ dan A. excelsa $84 \mathrm{~cm}$. Kemudian Syzigium sp dengan diameter $64 \mathrm{~cm}$ dan L. sundaicus serta
M. rhizinoides dengan diameter $<50 \mathrm{~cm}$. Untuk jenis pohon lainnya diameter bervariasi dimulai hingga $10-40 \mathrm{~cm}$. Adanya diameter batang yang kecil dan besar dipengaruhi oleh umur seperti masih muda dan kriteria pohon tersebut apakah termasuk pohon dengan diameter besar ataupun kecil. Pohon dengan diameter besar, memiliki pengaruh besar terhadap kehadiran anggrek epifit. Hasil pengamatan menunjukkan bahwa pohon dengan diameter besar lebih banyak dijumpai anggrek epifit (Sujalu, 2008).

Hal tersebut dikarenakan diameter batang pohon akan mempengaruhi tinggi dan lebar 
kanopi suatu. Dimana pohon dengan diameter besar menandakan bahwa pohon tersebut sudah tua yang ditandai dengan tinggi pohon dan lebar kanopi yang besar juga. Tinggi dan lebar kanopi sangat mempengaruhi kehadiran anggrek epifit. Tinggi pohon inang dengan rata-rata tertinggi berturut-turut yaitu Elaeocarpus sp $51 \mathrm{~m}, A$. excelsa $36 \mathrm{~m}$, C. tungurrut $34 \mathrm{~m}$, L. sundaicus 33 $\mathrm{m}$, dan $S$. rostratum $30 \mathrm{~m}$. Kemudian untuk lebar kanopi dengan rata-rata tertinggi berturut-turut yaitu L. sundaicus $20 \mathrm{~m}$, Elaeocarpus $18 \mathrm{~m}$, Syzigium sp $17 \mathrm{~m}, C$. tungurrut dan $M$. rhizinoides $15 \mathrm{~m}$, serta $A$. excelsa $14 \mathrm{~m}$. Kondisi kanopi pohon inang di Jalur Curug Cibereum cenderung tidak terlalu rapat walaupun memiliki ukuran kanopi yang lebar, sehingga masih banyak jenis anggrek epifit yang ditemukan. Hal tersebut karena pohon dengan kanopi yang terlalu rapat tidak banyak dijumpai anggrek epifit karena cahaya matahari akan terhalang masuk pada bagian anggrek epifit itu tumbuh (Seitske $e t$ al., 2001 dalam Yulia \& Rizki, 2010). Rindangnya tutupan kanopi pohon dipengaruhi oleh ukuran dan struktur percabangannya yang relatif besar, lebar, dan mendatar akan memungkinkan terkumpulnya dan terbentuknya humus sehingga benih-benih anggrek epifit tidak mudah hanyut oleh air melalui aliran kanopi maupun aliran batang. Akan tetapi pada pohon inang dengan kanopi pohon sudah rusak, meranggas dan hampir gundul atau sudah gundul tidak banyak dijumpai anggrek epifit (Sujalu, 2017). Hal tersebut seperti pada pohon mati yang hanya dijumpai 4 jenis anggrek epifit yaitu $A$. elegans, E. iridifolia, Bulbophyllum sp 3, dan $S$. juncifolia.
Sebagian besar pohon inang memiliki ketebalan kulit diatas $0.5 \mathrm{~cm}$. Adapun ketebalan kulit pohon dibawah $0.5 \mathrm{~cm}$ yaitu $D$. abnore, $F$. grewiifolia, S. laxiflorum, T. orientalis, dan pohon mati. Ketebalan kulit pada Cyathea sp 0, karena tidak dapat diukur yang disebabkan oleh batangnya ditempeli oleh paku epifit lain yang memiliki akar kuat sehingga permukaannya sangat keras. Ketebalan kulit tertinggi $(>1 \mathrm{~cm})$ yaitu pada $M$. rhizinoides $1.2 \mathrm{~cm}, S$. walichii dan E. acronodia sebesar $1 \mathrm{~cm}$. Anggrek epifit umumnya menyukai pohon inang dengan kulit yang tebal, kasar, retak-retak, banyak lekukan, dan lubang-lubang. Kondisi fisik kulit ini memungkinkan penimbunan serasah atau humus dan berkaitan erat dengan ketersediaan air dan hara yang menguntungkan tumbuh dan berkembangnya anggrek epifit (Sujalu 2008). Kulit pohon yang stabil lebih banyak dijumpai anggrek epifit karena lebih mampu menahan massa anggrek dan lebih kokoh sebagai tempat melekatnya anggrek. Pada pohon yang berkulit labil sedikit dijumpai anggrek epifit karena kulit pohon mudah mengalami pelapukan yang menyebabkan kulitnya mudah mengelupas sehingga tidak mampu mempertahankan keberadaan anggrek epifit (Atmaja \& Asri, 2015). Akan tetapi, tidak semuanya pohon yang berkulit tebal ditempeli banyak anggrek epifit. Pohon $M$. rhizinoides hanya ditempeli oleh anggrek Phreatia sp, $C$. speciosa, dan E. iridifolia, sedangkan pada inang E. acronodia hanya ditempeli anggrek $S$. juncifolia. Berdasarkan pengamatan, kedua pohon tersebut kondisinya tidak terlalu lembab sehingga anggrek epifit tidak banyak menempel pada pohon tersebut.

Tabel 4. Karakterisrik pohon inang anggrek Epifit di jalur Curug Cibereum

\begin{tabular}{llllll}
\hline \multirow{2}{*}{ No } & \multirow{2}{*}{ Nama Latin } & \multirow{2}{*}{ Nama Lokal } & \multicolumn{2}{c}{ Karakteristik Pohon Inang Anggrek Epifit } \\
\cline { 4 - 6 } & & Tekstur Kulit & Getah & Warna Kulit \\
\hline 1 & A. rotundifolium & Ki Careuh & Kasar & Tidak ada & Coklat \\
2 & A. excelsa & Rasamala & Medium & Tidak ada & Coklat \\
3 & B. glomerulata & Juluk-julukantu & Kasar & Tidak ada & Coklat \\
4 & B. insulana & Ki Pahang & Kasar & Tidak ada & Coklat \\
5 & C. argentena & Saninten & Kasar & Tidak ada & Coklat \\
6 & C. javanica & Riung Anak & Kasar & Tidak ada & Coklat \\
7 & C. tungurrut & Ki Tungeureut & Kasar & Tidak ada & Coklat \\
8 & C. timorensis & Ki Tamiang & Kasar & Tidak ada & Coklat \\
& & & 715 & &
\end{tabular}




\begin{tabular}{|c|c|c|c|c|c|}
\hline \multirow[t]{2}{*}{ No } & \multirow{2}{*}{ Nama Latin } & \multirow{2}{*}{ Nama Lokal } & \multicolumn{3}{|c|}{ Karakteristik Pohon Inang Anggrek Epifit } \\
\hline & & & Tekstur Kulit & Getah & Warna Kulit \\
\hline 9 & Cyathea sp & Paku Tiang & Kasar & Tidak ada & Hitam \\
\hline 10 & D. abnore & Kokopian & Kasar & Tidak ada & Coklat \\
\hline 11 & E. acronodia & Mendang & Kasar & Tidak ada & Coklat \\
\hline 12 & Elaeocarpus sp & - & Kasar & Tidak ada & Coklat \\
\hline 13 & E. stipularis & Janitri Gede & Kasar & Tidak ada & Coklat \\
\hline 14 & E. spicata & Ki Hujan & Kasar & Tidak ada & $\begin{array}{l}\text { Coklat } \\
\text { Coklat kehijauan }\end{array}$ \\
\hline 15 & E. acuminata & Ki Sapu & Kasar & Tidak ada & Coklat \\
\hline 16 & $F$. grewiifolia & - & Kasar & Tidak ada & Abu-abu hijau \\
\hline 17 & F. variegata & Kondang & $\begin{array}{l}\text { Kasar, } \\
\text { Medium }\end{array}$ & Putih & Coklat \\
\hline 18 & L.sundaicus & Pasang & Kasar & Tidak ada & Coklat \\
\hline 19 & M. rhizinoides & Mahang Perak & Kasar & Tidak ada & $\begin{array}{l}\text { Cokla } \\
\text { Coklat kehijauan }\end{array}$ \\
\hline 20 & N. obtusa & Cangcaratan & Kasar & Tidak ada & Coklat \\
\hline 21 & O. rubescens & Ngangsi & Kasar & Tidak ada & Coklat \\
\hline 22 & O. hexandra & Sauheun & Kasar & Tidak ada & Coklat \\
\hline 23 & P. arborea & Ceri Kawoyang & Kasar & Tidak ada & Coklat \\
\hline 24 & S. blumiana & Ki Leho & Kasar & Tidak ada & Coklat \\
\hline 25 & S. aromatica & Jangkorang & Kasar & Tidak ada & Coklat \\
\hline 26 & S. wallichii & Puspa & $\begin{array}{l}\text { Kasar } \\
\text { Medium }\end{array}$ & Tidak ada & Coklat \\
\hline 27 & S. sigun & Beleketebe & Kasar & Tidak ada & $\begin{array}{l}\text { Coklat } \\
\text { Coklat kehitaman }\end{array}$ \\
\hline 28 & S. rostratum & Ki Sereum & Kasar & Tidak ada & Coklat \\
\hline 29 & Syzigium sp & Salam & Kasar & Tidak ada & Coklat \\
\hline 30 & S. laxiflorum & Tiangpang & Kasar & Tidak ada & Coklat \\
\hline 31 & T. orientalis & Kuray & Kasar & Tidak ada & Abu-abu hijau \\
\hline 32 & T. pomifera & Ki Bancet & Kasar & Tidak ada & Coklat \\
\hline 33 & Pohon mati & Pohon mati & Kasar & Tidak ada & Coklat \\
\hline
\end{tabular}

Pengukuran karakteristik pohon inang selain dari kondisi fisik pohon juga berdasarkan parameter morfologi yang meliputi kondisi kulit pohon, ada tidaknya getah, dan warna kulit pohon. Kondisi kulit pohon inang anggrek epifit di Jalur Curug Cibereum sebagian besar memiliki kondisi kulit yang kasar. Akan tetapi ada juga yang memiliki kulit intermediet (tidak terlalu kasar). Kulit pohon yang tidak terlalu kasar disebabkan oleh usia pohon inang tersebut, dimana pohon tersebut masih muda (kecil). Kondisi kulit pohon inang yang kasar dan retakretak memiliki jenis anggrek yang lebih banyak dibandingkan dengan pohon yang memiliki tipe kulit batang yang licin. Kulit batang yang kasar dan retak merupakan habitat yang cocok untuk melekatnya biji anggrek (Budi et al., 2016). Hal tersebut karena biji anggrek akan mudah tersangkut pada batang yang memiliki kulit kasar dan retak sehingga memungkinkan terjadinya proses perkecambahan biji (Effendi et al., 2019).

Kemudian untuk ada tidak getahnya pada pohon inang, dari 33 jenis pohon inang terdapat 1 jenis pohon inang yang bergetah yakni $F$. variegata. Pohon tersebut memiliki getah berwarna putih. Walaupun memiliki getah, tetapi $F$. variegata merupakan salah satu pohon inang yang paling banyak dijumpai jenis anggrek epifit dalam satu pohon dibanding dengan pohon lainnya. Banyaknya jenis anggrek yang ditemukan pada pohon tersebut, menandakan bahwa getah pohon tersebut tidak berbahaya bagi 
anggrek epifit. Alasan anggrek epifit banyak ditemukan pada pohon tersebut karena berukuran besar, kanopi lebar, dan kondisi kulit batangnya lebih lembab dibanding dengan pohon lainnya yang mengindikasikan bahwa pohon tersebut memiliki kandungan air yang banyak. Banyaknya jenis anggrek epifit di sepanjang Jalur Curug Cibereum yang ditemukan pada pohon tidak bergetah menunjukkan bahwa anggrek epifit kurang menyukai kulit pohon yang memiliki getah. Alasan anggrek epifit tidak menempel pada pohon yang memiliki getah karena dikhawatirkan adanya kandungan zat yang berbahaya pada getah tersebut, sehingga dapat menganggu pertumbuhan anggrek epifit (Atmaja \& Asri, 2015).

Warna kulit pohon inang yang berasosiasi dengan anggrek epifit di Jalur Curug Cibereum pada dasarnya berwarna coklat. Namun terdapat beberapa kombinasi seperti coklat kehijauan, coklat kehitaman, hingga abu-abu kehijauan. Selain itu juga terdapat warna kulit pohon hitam. Perbedaan-perbedaan warna kulit pohon tersebut memang disebabkan karena karena faktor umur, kondisi lingkungan sekitar, dan intensitas sinar matahari yang menyinari pohon tersebut (Atmaja et al., 2015). Berdasarkan hasil pengamatan, warna hitam pada kulit pohon Cyathea sp (paku tiang) karena adanya akar dari paku epifit lain yang menutupi seluruh kulit pohon. Kemudian untuk warna kehijauan disebabkan karena adanya lumut yang menempel pada kulit pohon inang. Warna coklat kehitaman disebabkan karena usia pohon yang cukup tua, dan warna abu-abu kehijauan disebabkan karena adanya lichen yang menempel pada kulit pohon. Adanya lumut pada kulit pohon juga mempengaruhi pertumbuhan anggrek epifit. Ketebalan lumut pada kulit pohon inang yang mempengaruhi keberadaan anggrek epifit terdiri dari 3 kategori yaitu tebal $(>5 \mathrm{~cm})$, sedang $(2-5 \mathrm{~cm})$, dan tipis $(<1 \mathrm{~cm})$. Berdasarkan beberapa penelitian, anggrek epifit lebih menyukai adanya lumut yang tipis untuk pertumbuhannya (Tirta dan Sutomo, 2014). Hal tersebut karena lumut yang tebal dapat menganggu pertumbuhan anggrek seperti tidak dapat menempel sempurna pada batang pohon.

\section{Kesimpulan}

Ditemukan sebanyak 33 jenis pohon inang anggrek epifit ( 1 jenis berupa pohon mati) dari 20 Famili. Jenis-jenis anggrek yang ditemukan pada pohon inang yaitu 31 jenis yang terdiri dari 12 genus. Semua jenis inang anggrek epifit berupa pohon kecuali pada Cyathea sp berupa tiang dan Brassaiopsis glomerulata berupa perdu. Karakteristik pohon inang yang digunakan sebagai habitat anggrek epifit memiliki tinggi pohon antara 4-51 m, diameter batang pohon 7$89 \mathrm{~cm}$, lebar kanopi sebesar 0-20 m, ketebalan kulit sebesar 0-1.2 cm, kulit pohon sebagian besar bertekstur kasar, umumnya berwarna coklat, tidak bergetah kecuali pada pohon Ficus variegata, dan terdapat lumut.

\section{Ucapan Terima kasih}

Terimakasih kepada Balai Besar Taman Nasional Gunung Gede Pangrango dan Bidang Pengelolaan Taman Nasional Wilayah II Sukabumi yang sudah memberikan izin penelitian. Kepada Seksi Pengelolaan Taman Nasional Wilayah III Selabintana yang sudah memberikan dukungan, fasilitas, dan bantuan selama penelitian. Kepada rekan penelitian (Dharfan, Ali, Aulya) yang sudah membantu dalam proses pengambilan data.

\section{Referensi}

Atmaja, M. B \& Asri, C. P. (2015). Tipe Morfologi dan Anatomi Kulit Batang Pohon Inang Anggrek Epifit Di Petak 5 Bukit Plawangan, Taman Nasional Gunung Merapi. Prosiding Seminar HUT Kebun Raya Cibodas Ke 159. https://www.researchgate.net/publication/ 278329347_TIPE_MORFOLOGI_DAN_ ANATOMI_KULIT_BATANG_POHON_I NANG_ANGGREK_EPIFIT_DI_PETAK 5_BUKIT_PLAWANGAN_TAMAN_NAS IONAL_GUNUNG_MERAPI_Morpholog y_and_Anatomy_of_Bark_of_Epiphytic_ Orchids_Host_Trees_in_Sector_5_of

Budiman, Fidelis. K., \& Sumarso (2016). Diversitas dan Karakter Kulit Batang Pohon Inang Anggrek Hitam (Coelogyne pandurata Lind.) di Kawasan Cagar Alam Kersik Luway. Jurnal Penelitian Alam 7(1):

11-14. 
https://jpal.ub.ac.id/index.php/jpal/article/ view/201

Desitarani, Harry, W., Hideki, M., Ismail, R., Rugayah. S \& Tukirin, P. (2014). Buku Panduan Lapangan Jenis-Jenis Tumbuhan Restorasi. Project on Capacity Building for Restoration of Ecosystem in Conservation Areas. ISBN 978-60214476-6-6

Effendi, S., Nunik, S. A., \& Tatik, C. (2019). Keanekaragaman dan Kelimpahan Anggrek Epifit Di Kaki Gunung Liangpran Kalimantan Timur. Jurnal Ilmu Hayati 18(3): 305-313. DOI: http://dx.doi.org/10.14203/beritabiologi.v $18 \mathrm{i} 3.3709$

Fandani, H.S. Mallomasang, S. N., \& Korja, N. (2018). Keanekaragaman Jenis Anggrek pada Beberapa Penangkaran di Desa Ampera dan Desa Karunia Kecamatan Palolo Kabupaten Sigi. Jurnal Warta Rimba 6(3): 14-20. http://jurnal.untad.ac.id/jurnal/index.php/ WartaRimba/article/view/11297/8711

Febriliani, Ningsih, S., \& Muslimin. (2013). Analisis Vegetasi Habitat Anggrek di Sekitar Danau Tambing Kawasan Taman Nasional Lore Lindu. Universitas Tadulako. Jurnal Warta Rimba 1(1): 1-9. http://jurnal.untad.ac.id/jurnal/index.php/ WartaRimba/article/view/1958

Hasanuddin (2010). Jenis Tumbuhan Anggrek Epifit di Kawasan Cagar Alam Jantho Kabupaten Aceh Besar (Variety of Epiphytic Orchids in Jantho Nature Reservation Aceh Besar Distric). Jurnal Biologi Edukasi 2(2): 1-9. DOI: https://doi.org/10.1234/jbe.v2i2.431

Marsusi., Cahyanto, M., Yudi, S., \& Siti, K. (2001). Studi Keanekaragaman Anggrek Epifit di Hutan Jobolarangan. Jurnal Biodiversitas 2(2): 150-158. https://smujo.id/biodiv/article/download/7 $\underline{02 / 724}$
Murtiningsih, I, Ningsih, S, \& Muslimin. (2016). Karakteristik Pohon Inang Anggrek Di Kawasan Taman Nasional Lore Lindu. Jurnal Warta Rimba (4)2: 32-39. http://jurnal.untad.ac.id/jurnal/index.php/ WartaRimba/article/view/8348

Paramitha, I. G. A. A. P., I Gede, P. A., \& Made, P. (2010). Keanekaragaman Anggrek Epifit di Kawasan Taman Wisata Alam Danau Buyan-Tamblingan. Jurnal Metamorfosa 1(1): 11-16. https://ojs.unud.ac.id/index.php/metamorf osa/article/view/6350

Prapitasari, B., Ardyan, P. K., \& Dadi, H. M. (2020). Keanekaragaman dan Kemelimpahan Jenis Anggrek (Orchidacae) di Resort Selabintana Taman Nasional Gunung Gede Pangrango (TNGGP) Jawa Barat. Jurnal Biosfer 5(1): 24-30.

DOI:http://dx.doi.org/10.23969/biosfer.v5 $\underline{\mathrm{i} 1.2569}$

Puspitanintyas, D. M. (2007). Inventarisasi Anggrek dan Inangnya di Taman Nasional Meru Betiri Jawa Timur. Jurnal Biodiversitas $\quad 8(3): \quad$ 210-214. https://biodiversitas.mipa.uns.ac.id/D/D0 803/D080309.pdf

Rozak, A. H., Sri, A., Zaenal, M., Didik, W., \& Endah, S. (2016). Kekayaan Jenis Pohon di Hutan Taman Nasional Gunung Gede Pangrango Jawa Barat. Jurnal Penelitian Hutan dan Konservasi Alam 13(1): 1-14. https://www.researchgate.net/publication/ 315819302_KEKAYAAN_JENIS_POH ON_DI_HUTAN_TAMAN_NASIONAL GUNUNG_GEDE_PANGRANGO_JA WA_BARAT_Tree_Species_Richness_in _Forest_of_Mount_Gede-

Pangrango_National_Park_West_Java

Sadili A. (2013). Jenis anggrek (Orchidaceae) di Tau Lumbis, Nunukan, Propinsi Kalimantan Timur; sebagai Indikator Terhadap Kondisi Kawasan Hutan. Jurnal Biologi Indonesia 9(1): 63-71. DOI: http://dx.doi.org/10.14203/jbi.v9i1.147 
Sadili, A \& Siti, S. (2017). Keanekaragaman, Sebaran, dan Pemanfaatan Jenis-Jenis Anggrek (Orchidaceae) di Hutan Bodogol, Taman Nasional Gede Pangrango, Jawa Barat. Jurnal Widyariset 3(2): 95-106. https://widyariset.pusbindiklat.lipi.go.id/i ndex.php/widyariset/article/view/475

Setyawan, A. D. (2000). Tumbuhan Epifit pada Tegakan Pohon Schima Walichii (D. C.) Korth. Di Gunung Lawu. Jurnal Biodiversitas 1(1):14-20. https://core.ac.uk/download/pdf/2695105 3.pdf

Siregar, C, Listiawati, A. \& Purwaningsih (2005). Anggrek Spesies Kalimantan Barat Volume I. Lembaga Penelitian dan Pengembangan Pariwisata Kalimantan Barat (LP3-KB). Jakarta: Jayakarta Agung Offset

Sujalu, A.P., Hardiwinarto, S., Boer, C. \& Sumaryono. (2015). Identifikasi Pohon Inang Epifit di Hutan Bekas Tebangan pada Dataran Rendah Daerah Aliran Sungai (DAS) Malinau. Jurnal Penelitian Ekosistem Dipterokarpa 1(1): 1-6. DOI: https://doi.org/10.20886/jped.2015.1.1.1$\underline{6}$

Sujalu, A. P. (2008). Analisis Vegetasi Keanekaragaman Anggrek Epifit di Hutan Bekas Tebangan, Hutan Penelitian Malinau (MRF)-Cifor. Jurnal Media Konservasi 13(3): 1-9. DOI: https://doi.org/10.29244/medkon.13.3.\%2 $\underline{5 p}$

Sujalu, A. P. (2017). Identifikasi Pohon Inang Epifit di Hutan Dipterocarpaceae Dataran Rendah Klimaks Kabupaten Malinau. Jurnal Hut Trop 1(2): 196 - 201. DOI: https://doi.org/10.32522/u-jht.v1i2.1014

Sumarni, S. Fatmah H., \& Hilda, K. (2019). Inventarisasi Jenis Pohon Inang Anggrek Epifit di Desa Tompobulu Resot Balocci Taman Nasional Bantimurung Bulusaraung Kabupaten Pangkep Provinsi Sulawesi Selatan. Jurnal Bionature 20(2):
96-108.

DOI:

https://doi.org/10.35580/bionature.v20i2. $\underline{11279}$

Syarif, A \& Efri, R. (2018). Studi Lichen pada Berbagai Tumbuhan Inang di Kecamatan Serengan, Kota Surakarta. Seminar Nasional Pendidikan Biologi Sanitek III 356-261.

http://hdl.handle.net/11617/10513

Toyama, H., Shuichiro, T., Dedy, D., Ibrahim, D., Marlina, A., Arief, H., Ahmad, J. A., Akiyo, N., Hidetoshi, N., Ryuji, I, \& Tetsukazu, Y. (2018). A picture Guide of Forest Trees in Gunung Gede Pangrango National Park, Indonesia. Center for Asian Concervation Ecology: Kyushu University. 384 pp.

Wawangningrum, H \& Dwi, M. S. (2008). Keanekaragaman Araliaceae di Suaka Alam Sulasih Talang, Sumatera Barat dan Aklimatisasinya. Jurnal Biodiversitas 9(2): 123-127. https://studylibid.com/doc/1418546/keane karagaman-araliaceae-di-suaka-alamsulasih-talang

Yulia, N. D \& Rizki, M. Y. (2010). Anggrek Epifit dan Pohon Inangnya di Kawasan Gunung Penanggungan, Pasuruan, Jawa Timur. Jurnal Berkala Penelitian Hayati Edisi Khusus 4A: 37-40. http://berkalahayati.org/files/journals/1/ar ticles/32/submission/32-102-1-SM.pdf 